\title{
2021 Update of the International Council for Standardization in Haematology Recommendations for Laboratory Measurement of Direct Oral Anticoagulants
}

\author{
Jonathan Douxfils ${ }^{1,20}$ Dorothy M. Adcock ${ }^{3}$ Shannon M. Bates ${ }^{4}$ Emmanuel J. Favaloro ${ }^{5}$ \\ Isabelle Gouin-Thibault ${ }^{6}$ Cecilia Guillermo ${ }^{7}$ Yohko Kawai ${ }^{8}$ Edelgard Lindhoff-Last ${ }^{9}$ Steve Kitchen ${ }^{10}$ \\ Robert C. Gosselin ${ }^{11}$
}

${ }^{1}$ Department of Pharmacy-Namur Thrombosis and Hemostasis

Address for correspondence Jonathan Douxfils, PharmD, PhD, Center, University of Namur, Namur, Belgium

${ }^{2}$ Qualiblood SA, Namur, Belgium University of Namur, Department of Pharmacy, Rue de Bruxelles, 61,

${ }^{3}$ Laboratory Corporation of America, Burlington North Carolina, 5000-Namur, Belgium (e-mail: jonathan.douxfils@unamur.be).

4 Department of Medicine, McMaster University Medical Centre, Hamilton, Ontario, Canada

${ }^{5}$ Department of Haematology, Sydney Centres for Haemostasis and Thrombosis, Institute of Clinical Pathology and Medical Research, NSW Health Pathology, Westmead Hospital, Westmead, New South Wales, Australia

${ }^{6}$ Department of Hematology-Hemostasis, IRSET-INSERM-1085, University Hospital, Rennes, France

${ }^{7}$ Hospital de Clínicas “Dr Manuel Quintela," Facultad de Medicina, Universidad de la República, Montevideo, Uruguay

${ }^{8}$ Sanno Hospital, Laboratory Medicine, Tokyo, Japan

${ }^{9}$ Cardiology Angiology Center Bethanien, CCB Vascular Center, CCB Coagulation Center, Frankfurt, Germany

10 Royal Hallamshire Hospital, Coagulation Sheffield, South Yorks, United Kingdom

11 Hemophilia Treatment Center, University of California, Davis Health System, Sacramento, California, United States

Thromb Haemost 2021;121:1008-1020.
Abstract
Keywords
- diagnosis management
- guidance
- direct oral anticoagulants
- laboratory

In 2018, the International Council for Standardization in Haematology (ICSH) published a consensus document providing guidance for laboratories on measuring direct oral anticoagulants (DOACs). Since that publication, several significant changes related to DOACs have occurred, including the approval of a new DOAC by the Food and Drug Administration, betrixaban, and a specific DOAC reversal agent intended for use when the reversal of anticoagulation with apixaban or rivaroxaban is needed due to lifethreatening or uncontrolled bleeding, andexanet alfa. In addition, this ICSH Working Party recognized areas where additional information was warranted, including patient population considerations and updates in point-of-care testing. The information in this manuscript supplements our previous ICSH DOAC laboratory guidance document. The recommendations provided are based on (1) information from peer-reviewed publications about laboratory measurement of DOACs, (2) contributing author's personal experience/expert opinion and (3) good laboratory practice. received

December 1, 2020 accepted after revision March 17, 2021 published online March 19, 2021 (c) 2021. Thieme. All rights reserved. Georg Thieme Verlag KG,

Rüdigerstraße 14 ,

70469 Stuttgart, Germany
DOI https://doi.org/ 10.1055/a-1450-8178. ISSN 0340-6245. 


\section{Introduction}

In 2018, the International Council for Standardization in Haematology (ICSH) published a consensus document providing guidance for laboratories on measuring direct oral anticoagulants (DOACs). ${ }^{1}$ Since that publication, several significant changes related to DOACs have occurred, including the approval of a specific DOAC reversal agent (intended for use when the reversal of anticoagulation with apixaban or rivaroxaban is needed due to life-threatening or uncontrolled bleeding), andexanet alfa (Andexxa in the United States and Ondexxya in the European Union) from Portola Pharmaceuticals Inc. ${ }^{2,3}$ Betrixaban (Bevyxxa, Portola), the fourth direct factor Xa (FXa) DOAC was approved for use in the United States but has since been discontinued by the manufacturer and will not be addressed. In addition, this ICSH Working Party recognized areas where additional information was warranted, including patient population considerations and updates in point-of-care testing (POCT). The information in this manuscript supplements our previous ICSH DOAC laboratory guidance document. ${ }^{1}$ The consensus recommendations provided are based on (1) information from peer-reviewed publications about laboratory measurement of DOACs, (2) contributing author's personal experience/expert opinion and (3) good laboratory practice.

\section{Patient Selection for DOAC Testing}

As with the first ICSH DOAC publication, whether or not patients should be tested is beyond the scope of this document. ${ }^{1,4-6}$ However, laboratory staff should be aware of emerging publications conveying potential advantages of measuring DOAC levels ( - Table 1 ). In addition to previously

Table 1 Indication for testing of direct oral anticoagulants (DOACs) according to the level of evidence for non-urgent situations

\begin{tabular}{|c|c|c|c|}
\hline Indication & Rationale & Practical consideration & Source of information \\
\hline \multicolumn{4}{|c|}{ Non-urgent situations } \\
\hline Advanced age & $\begin{array}{l}\text { Increased rate of bleeding events with } \\
\text { age and increased susceptibility of } \\
\text { bleeding events with DOAC } \\
\text { accumulation }\end{array}$ & $\begin{array}{l}\text { If done, plasma DOAC } \\
\text { concentrations should be } \\
\text { measured at trough, just } \\
\text { before the next pill or cap- } \\
\text { sule intake after } 5 \text { or more } \\
\text { intakes to ensure the DOAC } \\
\text { has reached its steady } \\
\text { state. Plasma DOAC con- } \\
\text { centration should be in the } \\
\text { range of concentrations } \\
\text { observed in other } \\
\text { populations }\end{array}$ & $\begin{array}{l}\text { Post hoc analyses of safety } \\
\text { outcome from phase } 3 \\
\text { clinical trials and post- } \\
\text { marketing observational } \\
\text { studies. } \\
\text { NB: Data are lacking to show } \\
\text { the benefit of adjusting the } \\
\text { dose based on individual } \\
\text { pharmacokinetic (PK) evalu- } \\
\text { ation, but these data sug- } \\
\text { gest that the optimal drug } \\
\text { level varies with age }\end{array}$ \\
\hline $\begin{array}{l}\text { Severe renal failure } \\
\text { and dialysis } \\
\text { dependence }\end{array}$ & $\begin{array}{l}\text { Increased levels of DOAC reflected by } \\
\text { increased } C_{\text {MAX }} \text { and AUC, especially for } \\
\text { dabigatran, rivaroxaban and edoxaban. } \\
\text { Apixaban seems less affected based on } \\
\text { PK studies. Bleeding risk and bleeding- } \\
\text { related death were increased signifi- } \\
\text { cantly in these population compared } \\
\text { with warfarin } \\
\text { NB: AHA, ACC, HRS and EHRA guidelines all } \\
\text { refrained from supporting use of dabiga- } \\
\text { tran, rivaroxaban and edoxaban in } \\
\text { patients with chronic kidney disease (CKD) } \\
\text { or on dialysis. Only warfarin and apixaban } \\
\text { seems to be safer in these populations }\end{array}$ & $\begin{array}{l}\text { If done, plasma DOAC } \\
\text { concentrations should be } \\
\text { measured at trough, just } \\
\text { before the next pill or cap- } \\
\text { sule intake after } 5 \text { or more } \\
\text { intakes to ensure the DOAC } \\
\text { has reached its steady } \\
\text { state. Plasma DOAC con- } \\
\text { centration should be in the } \\
\text { range of concentrations } \\
\text { observed in other } \\
\text { populations }\end{array}$ & $\begin{array}{l}\text { Post hoc analyses from } \\
\text { phase } 3 \text { clinical trials and } \\
\text { post-marketing observa- } \\
\text { tional studies } \\
\text { NB: Data are lacking to show } \\
\text { the benefit of adjusting the } \\
\text { dose based on individual PK } \\
\text { evaluation, but these data } \\
\text { suggest that the optimal } \\
\text { drug level varies with renal } \\
\text { function }\end{array}$ \\
\hline $\begin{array}{l}\text { Prior interventions } \\
\text { with high bleeding } \\
\text { risk }\end{array}$ & $\begin{array}{l}\text { To be on the safe side, intervention } \\
\text { categorized as being at high bleeding } \\
\text { risk should be done in patients with no or } \\
\text { undetectable DOAC concentration. } \\
\text { Using the PK approach would not ensure } \\
\text { all patients will have cleared completely } \\
\text { the DOAC as many variables could in- } \\
\text { terfere with the elimination of DOACs. } \\
\text { As some of the factors used to set up the } \\
\text { PK approach also rely on surrogate bio- } \\
\text { markers (e.g., serum creatinine or liver } \\
\text { function), the most obvious and ratio- } \\
\text { nale solution could be the measurement } \\
\text { of DOAC concentrations }\end{array}$ & $\begin{array}{l}\text { Plasma DOAC concentra- } \\
\text { tion should be measured } \\
\text { within a few hours before } \\
\text { the intervention and } \\
\text { planned surgical interven- } \\
\text { tion should proceed when } \\
\text { the level is considered low } \\
\text { enough. Plasma DOAC } \\
\text { concentration should be in } \\
\text { the range of concentra- } \\
\text { tions observed in other } \\
\text { populations }\end{array}$ & $\begin{array}{l}\text { Post-marketing observa- } \\
\text { tional studies } \\
\text { NB: there are currently no } \\
\text { prospectively validated data } \\
\text { with hard clinical endpoints } \\
\text { on cut-off values of any co- } \\
\text { agulation test to guide the } \\
\text { timing of elective or urgent } \\
\text { surgery }\end{array}$ \\
\hline
\end{tabular}


Table 1 (Continued)

\begin{tabular}{|c|c|c|c|}
\hline Indication & Rationale & Practical consideration & Source of information \\
\hline \multicolumn{4}{|c|}{ Non-urgent situations } \\
\hline $\begin{array}{l}\text { Body mass index } \\
\text { (BMl above) } \\
40 \mathrm{~kg} / \mathrm{m}^{2}\end{array}$ & $\begin{array}{l}\text { For patient with BMI above } 40 \mathrm{~kg} / \mathrm{m}^{2} \text {, if a } \\
\text { DOAC is chosen, obtaining a peak and } \\
\text { trough DOAC concentration estimate } \\
\text { after at least } 5 \text { doses may be of interest } \\
\text { to ensure the plasma concentrations are } \\
\text { roughly within the range published for } \\
\text { other patients } \\
\text { NB: It remains unclear whether adequate } \\
\text { DOAC concentrations are achieved to be } \\
\text { clinically effective. The majority of post hoc } \\
\text { analyses showed reassuring data for } \\
\text { patients up to } 40 \mathrm{~kg} / \mathrm{m}^{2} \text { but further data } \\
\text { are needed in extreme obese }\end{array}$ & $\begin{array}{l}\text { If done, plasma DOAC } \\
\text { concentrations should be } \\
\text { measured at trough, just } \\
\text { before the next pill or cap- } \\
\text { sule intake and at peak af- } \\
\text { ter } 5 \text { or more intakes to } \\
\text { ensure the DOAC has } \\
\text { reached its steady state. } \\
\text { Plasma DOAC concentra- } \\
\text { tion should be in the range } \\
\text { of concentrations ob- } \\
\text { served in other } \\
\text { populations. }\end{array}$ & $\begin{array}{l}\text { PK studies and expert } \\
\text { opinion }\end{array}$ \\
\hline Drug interactions & $\begin{array}{l}\text { Numerous drug interactions have been } \\
\text { described and investigated by the man- } \\
\text { ufacturers, sometimes requiring dose } \\
\text { adaptations. However, unknown drug } \\
\text { interactions as well as multiple drug } \\
\text { interactions may interfere with drug } \\
\text { levels to a degree, which may have a } \\
\text { clinical relevance. Evaluating DOAC lev- } \\
\text { els in these conditions may identify drug } \\
\text { accumulation or clearance }\end{array}$ & $\begin{array}{l}\text { If done, plasma DOAC } \\
\text { concentrations should be } \\
\text { measured at trough, just } \\
\text { before the next pill or cap- } \\
\text { sule intake after } 5 \text { or more } \\
\text { intakes to ensure the DOAC } \\
\text { has reached its steady } \\
\text { state. Plasma DOAC con- } \\
\text { centration should be in the } \\
\text { range of concentrations } \\
\text { observed in other } \\
\text { populations }\end{array}$ & $\begin{array}{l}\text { PK studies, case reports } \\
\text { and post-marketing obser- } \\
\text { vational studies }\end{array}$ \\
\hline
\end{tabular}

indicated clinical situations (usually urgent situations) where DOAC measurements may be useful, ${ }^{1,6}$ evidence is accumulating between drug exposure and clinical outcome (-Table 2). ${ }^{7-11}$ Additional data, albeit low grade, may support other situations and patients who may benefit from DOAC assessment. ${ }^{12,13}$ Included are patients with advanced age, ${ }^{14,15}$ severe renal failure and dialysis dependence, ${ }^{15,16}$ as well as patients with acute bleeding, to determine appropri- ate reversal strategies and associated dosing required. ${ }^{17-19}$ Some have also suggested DOAC measurements in patients the day prior to undergoing interventions with high bleeding risk (e.g., complex endoscopy, spinal or epidural anesthesia, thoracic surgery, abdominal surgery, major orthopaedic surgery or neurosurgery), ${ }^{5,20-23}$ although it should be noted that this approach of measuring DOACs is currently not supported by clinical evidence and the relevance of the

Table 2 Indication for testing of direct oral anticoagulants according to level of evidence for urgent situations

\begin{tabular}{|c|c|c|c|}
\hline Indication & Rationale & Practical recommendation & $\begin{array}{l}\text { Source of infor- } \\
\text { mation }\end{array}$ \\
\hline \multicolumn{4}{|l|}{ Urgent situations } \\
\hline $\begin{array}{l}\text { Acute bleeding and } \\
\text { determination of } \\
\text { appropriate rever- } \\
\text { sal strategies }\end{array}$ & $\begin{array}{l}\text { Measuring the anticoagulant effects or } \\
\text { plasma drug levels of DOAC can help } \\
\text { determine their contribution to bleeding } \\
\text { or to determine when it is safe to per- } \\
\text { form an urgent or unplanned interven- } \\
\text { tion. Assessing potential rebound effect } \\
\text { after administration of reversal agents } \\
\text { NB: Delaying antidote administration until } \\
\text { coagulation test results are available may } \\
\text { be detrimental in DOAC-treated patients } \\
\text { with life-threatening bleeding, such as in- } \\
\text { tracranial bleeding or in those requiring } \\
\text { emergency surgery for life-threatening } \\
\text { conditions such as a ruptured aortic } \\
\text { aneurysm }\end{array}$ & $\begin{array}{l}\text { Measurement of plasma DOAC } \\
\text { concentration should be done as } \\
\text { soon as possible } \\
\text { NB: Recommendations for antidote } \\
\text { administration are based on plasma } \\
\text { DOAC concentrations. In patients } \\
\text { with serious bleeding, a DOAC } \\
\text { concentration > } 50 \mathrm{ng} / \mathrm{mL} \text { is consid- } \\
\text { ered sufficiently high to warrant an- } \\
\text { tidote administration, whereas in } \\
\text { those requiring an urgent interven- } \\
\text { tion associated with a high risk of } \\
\text { bleeding, antidote administration } \\
\text { should be considered if the DOAC } \\
\text { concentration exceeds } 30 \mathrm{ng} / \mathrm{mL}\end{array}$ & $\begin{array}{l}\text { Case series and ex- } \\
\text { pert opinions. Post } \\
\text { hoc analyses from } \\
\text { phase } 3 \text { clinical tri- } \\
\text { als and case series }\end{array}$ \\
\hline
\end{tabular}


current threshold is questioned. ${ }^{24}$ Specifically, although the "Perioperative Anticoagulant Use for Surgery Evaluation" (PAUSE) study reported acceptable bleeding rates with their clinically defined anticoagulant interruption strategies and defined thresholds, that is, analyses were done for residual DOAC levels $\geq 30 \mathrm{ng} / \mathrm{mL}$ and $\geq 50 \mathrm{ng} / \mathrm{mL},{ }^{25,26}$ it is not known what DOAC level would be considered "safe" to undergo a surgical procedure or intervention and with the vast majority of patients, a wait time period appears to be safe. ${ }^{25,26}$ With limited data on patients with a body mass index (BMI) $>40 \mathrm{~kg} / \mathrm{m}^{2}$, DOAC pharmacokinetic and/or pharmacodynamic measurements in this population may be considered. ${ }^{27,28}$ In addition, many elderly patients with non-valvular atrial fibrillation may acutely develop decompensated heart insufficiency with increase of liver enzymes, decreased intestinal blood flow and develop an unpredictable pharmacokinetic profile which may lead to an increased bleeding risk. DOAC measurements may be useful in detecting DOAC overexposure and bleeding risk, DOAC underexposure and thrombotic risk, and identifying previously undescribed and described drug-drug interactions, although this needs to be confirmed in larger cohorts. ${ }^{29-31}$ It should be noted that paediatric patients may have lower DOAC levels than adults, ${ }^{32}$ and modifications of anti-Xa methods may be required. In addition, discrete age-partitioned and age-appropriate reference intervals are likely needed for coagulation test in the paediatric population. ${ }^{33}$

\section{Consensus Recommendations}

- This ICSH Working Party recognizes there are insufficient data to date for providing dose-adjustment recommendations based on DOAC levels alone. Nevertheless, DOAC measurements may identify potential excessive clearance or drug accumulation and could be used in situations where the benefit of such measurement is likely to outweigh the risk, for example, in non-urgent situations.

- Several categories of patients may benefit from DOAC level measurements to ensure they are within the concentration range observed in pharmacokinetic investigations during drug developments.

- If a DOAC measurement has been requested for urgent purpose, results should be provided within 30 minutes to aid in acute clinical decision-making.

- This ICSH Working Party encourages laboratories to provide DOAC measurements per clinical need. DOAC results must be used (and interpreted) in the context of patient history, DOAC type, DOAC dose, last dose and potential impact on clinical management (e.g., surgical intervention, bleeding, reversal strategies).

\section{DOAC and Laboratory Testing}

The first ICSH laboratory DOAC guidance document already detailed test procedures or methods for quantifying DOACs such as the ecarin clotting time (ECT), dilute thrombin time (dTT) or anti-Xa measurements (-Fig. 1). ${ }^{1}$ More methodological details can also be found elsewhere. ${ }^{34-36}$ Of particular note, the ECT used in the dabigatran trials and the ECT range cited in prescriber information are based on an ECT reagent concentration of $6 \mathrm{IU} / \mathrm{mL} .^{35}$

\section{Interference of DOAC on Coagulation Assays}

It has been widely shown that DOACs may interfere with coagulation testing, even at low DOAC concentrations. ${ }^{37}$ Thus, even trough collections aimed to minimize DOAC concentration may be inadequate to completely eliminate drug interference in certain assays. ${ }^{37}$ To ensure an undetectable DOAC concentration, a delay of 3 days or more (depending on DOAC, renal function and clinical situations) between the last intake and testing could be necessary. A longer delay is likely necessary for lupus anticoagulant (LA) testing with dilute Russell viper venom time (dRVVT) tests, due to the interference that may still be present when DOAC concentration is below the lower limit of quantification of the anti-Xa-based method (anti-Xa). However, due to high inter-individual DOAC variability and potential thrombotic risk, a wait period of 3 days may not be a suitable alternative unless bridging therapy (e.g., lowmolecular-weight heparin [LMWH]) is considered. ${ }^{38}$ Alternatively, in vitro removal of DOAC compounds from plasma prior to coagulation testing has been reported and may be more suitable. ${ }^{39-47}$ DOAC-Stop (adsorbing agent, Hematex Research, Hornsby, Australia) and DOAC-Remove (activated carbon, 5-Diagnostics, Basel, Switzerland), both reportedly able to neutralize all DOACs with minimal effect on haemostasis tests, have been recently commercialized. ${ }^{39-47}$ However, care should be taken, especially in LA testing, since in the reported studies, complete reversal did not occur in every sample and reversal varies among the different DOACs. ${ }^{42,43,45,48,49}$ Some differential effects may be observed between use of DOAC-Stop and use of DOAC-Remove since these products are not identical or necessarily interchangeable.

Additionally, a slight procoagulant effect of DOAC-Stop has been shown in thrombin generation assays (TGAs) that use an intermediate concentration of tissue factor (i.e., around 5 pM). This procoagulant effect seems to be related to slight reduction in tissue factor pathway inhibitor (TFPI). ${ }^{50,51}$ The elimination of DOAC presence in plasma using filters like the DP-Filter (5-Diagnostics) or the DOAC-Filter (Diagnostica Stago, France) showed promising results. ${ }^{39,52}$ However, potential unintended filtration of coagulation proteins seen with other filtering mechanisms (e.g., von Willebrand factor) may occur, but the interference of DOAC-Stop or DOAC-Remove on these other coagulation proteins has also been found (e.g., interference on TFPI), impacting mainly TGA. ${ }^{51}$ Lastly, new products are currently under evaluation that demonstrates low to no DOAC interference for LA detection. ${ }^{53,54}$

\section{Interference of DOAC on Platelet Aggregation and Fibrinolysis Assays}

Sokol et al demonstrated a reduction in thrombin-induced platelet aggregation with rivaroxaban and apixaban, a result different from a previous investigation with rivaroxaban. $^{55,56}$ This requires further investigations and 

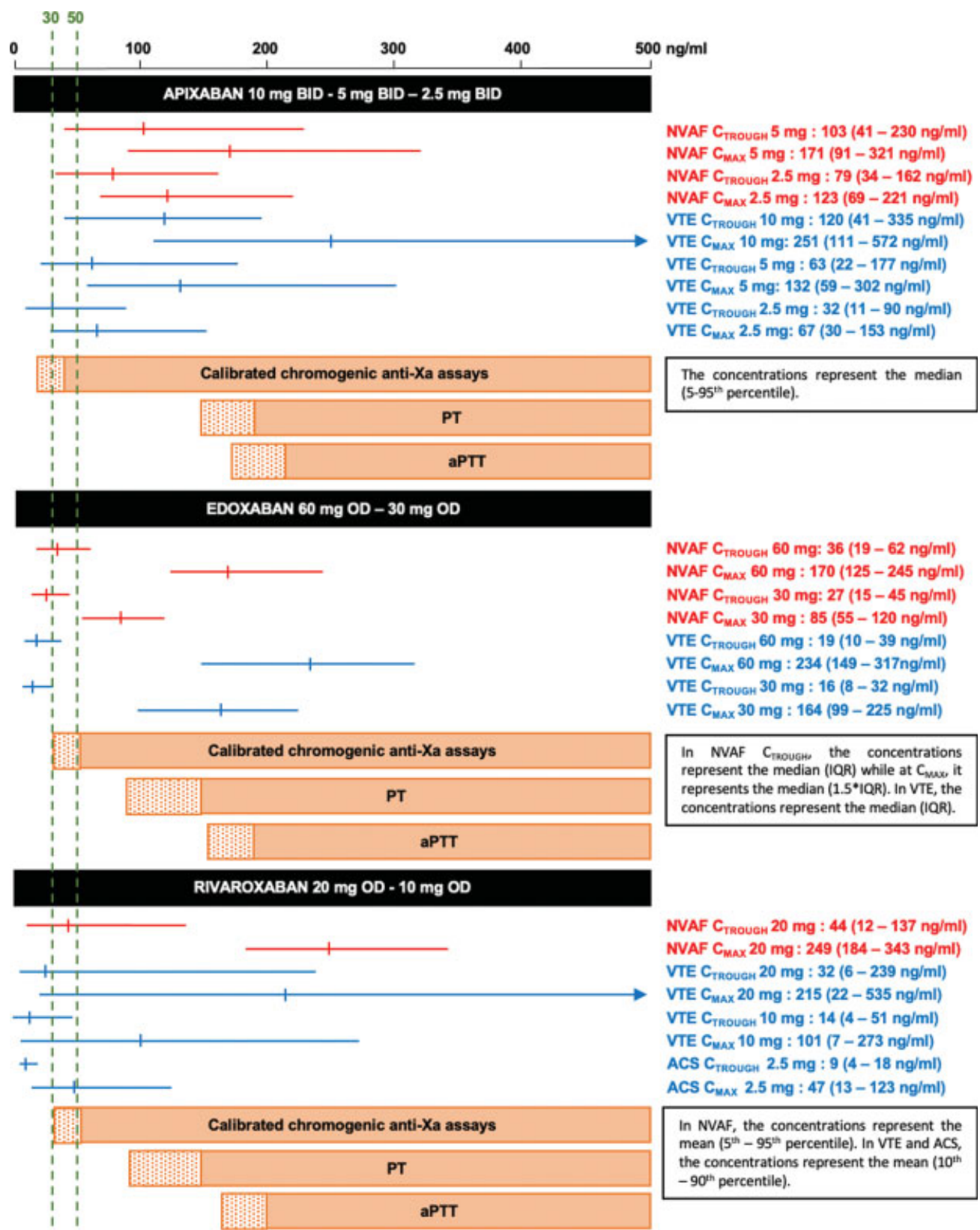

NVAF C TROUGH $_{\text {Th }} 60 \mathrm{mg}: 36(19-62 \mathrm{ng} / \mathrm{ml})$ NVAF $C_{\max } 60 \mathrm{mg}: 170(125-245 \mathrm{ng} / \mathrm{ml})$ NVAF $C_{\text {Trouch }} 30 \mathrm{mg}: 27(15-45 \mathrm{ng} / \mathrm{ml})$ NVAF $\mathrm{C}_{\text {wax }} 30 \mathrm{mg}$ : $85(55-120 \mathrm{ng} / \mathrm{ml})$ VTE C $C_{\text {ThочG: }} 60 \mathrm{mg}: 19(10-39 \mathrm{ng} / \mathrm{ml})$ VTE C $C_{\max } 60 \mathrm{mg}: 234(149-317 \mathrm{ng} / \mathrm{ml})$ VTE $C_{\text {TROUGH }} 30 \mathrm{mg}: 16(8-32 \mathrm{ng} / \mathrm{ml})$ VTE $C_{\text {max }} 30 \mathrm{mg}: 164(99-225 \mathrm{ng} / \mathrm{ml})$

In NVAF $\mathrm{C}_{\text {roougits }}$ the concentrations represent the median (IQR) while at $C_{\text {mor }}$ it represents the median (1.5*IQR). In VTE, the concentrations represent the median (IQR).

DABIGATRAN $150 \mathrm{mg}$ BID

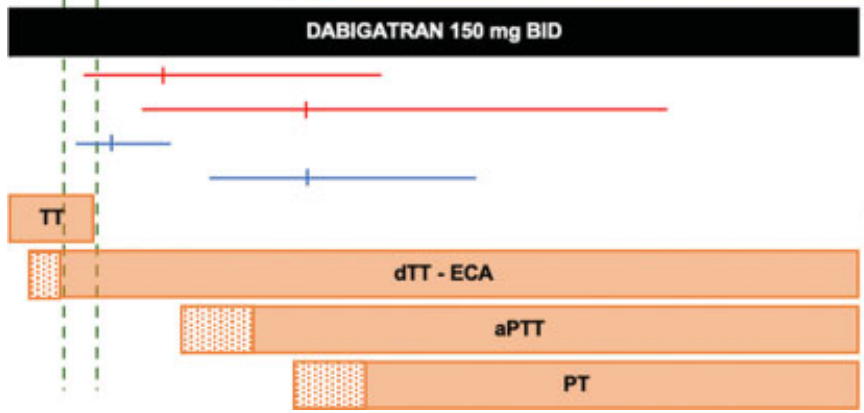

NVAF $\mathrm{C}_{\text {Troueh }} 20 \mathrm{mg}$ : 44 (12 - $\left.137 \mathrm{ng} / \mathrm{ml}\right)$ NVAF $C_{\max } 20 \mathrm{mg}: 249$ (184 - $\left.343 \mathrm{ng} / \mathrm{ml}\right)$ VTE C Trougu $20 \mathrm{mg}$ : 32 (6- $239 \mathrm{ng} / \mathrm{ml})$ VTE C $C_{\text {MAX }} 20 \mathrm{mg}$ : $215(22-535 \mathrm{ng} / \mathrm{ml})$ VTE $C_{\text {TROUGH }} 10 \mathrm{mg}: 14(4-51 \mathrm{ng} / \mathrm{ml})$ VTE $C_{\text {wax }} 10 \mathrm{mg}$ : 101 (7 - $\left.273 \mathrm{ng} / \mathrm{ml}\right)$ ACS C ACS $C_{\text {MAx }} 2.5 \mathrm{mg}: 47$ (13-123 ng/ml)

In NVAF, the concentrations represent the mean $\left(5^{\text {th }}-95^{\text {th }}\right.$ percentile). In VTE and ACS, the concentrations represent the mean $\left(10^{\text {th }}\right.$ $-90^{\text {th }}$ percentile).

NVAF C TROUGH $_{\text {: }} 91$ (40 - $\left.215 \mathrm{ng} / \mathrm{ml}\right)$ NVAF $\left.C_{\text {max }}: 175(74-383) \mathrm{ng} / \mathrm{ml}\right)$ VTE $C_{\text {Thоля }}$ : 60 (39- $\left.95 \mathrm{ng} / \mathrm{ml}\right)$ VTE C $C_{\text {MAX }}$ : 175 (117 - 275 ng/ml)

In NVAF, the concentrations represent the mean $\left(10^{\text {th }}-90^{\text {th }}\right.$ percentile). In VTE, the concentrations represent the median (IQR).

Fig. 1 Laboratory testing for direct oral anticoagulant (DOAC) and expected plasma concentrations after therapeutic doses. Orange boxes represent ranges of applicability of the corresponding test. Dashed orange boxes represent the zone in which the variability may change due to different reagent sensitivities. Note that only reagents considered as sensitive/reactive were considered. Plasma concentration ranges are extracted from the European Summary of Product Characteristics for all indications of apixaban ${ }^{128}$ and dabigatran ${ }^{129}$ and for VTE and ACS indications of rivaroxaban, ${ }^{130}$ from Mueck et al for rivaroxaban in NVAF, ${ }^{131}$ and from Ruff et al, ${ }^{7}$ Weitz et al ${ }^{132}$ and Verhamme et al ${ }^{133}$ for edoxaban. (ACS, acute coronary syndrome; APTT, activated partial thromboplastin time; $C_{\text {MAX }}$, maximum plasma concentration during the dosing interval; $C_{\text {TROUGH }}$, minimum plasma concentration during the dosing interval; dTT, diluted thrombin time; ECA, ecarin chromogenic assay; IQR, interquartile range; NVAF, non-valvular atrial fibrillation; PT, prothrombin time; TT, thrombin time; VTE, venous thromboembolism.) 
confirmations. As expected, a similar effect has been reported by Shimizu et al with dabigatran. ${ }^{57}$ However, the interference with platelet aggregation is most likely an indirect effect of DOACs driven by the inhibition of thrombin generation. ${ }^{58}$ Additionally, it has been shown that dabigatran, rivaroxaban, and apixaban enhance fibrinolysis, but this depends on the presence of thrombomodulin in the test system. ${ }^{59-62}$ As such, caution should be used when performing and interpreting the results from any coagulation-related test from a DOAC-treated patient. ${ }^{37}$

\section{Management of Heparin Bridging in DOAC Treated Patients}

DOAC-treated patients may suffer an acute event that requires bridging with unfractionated heparin (UFH) or LMWH. For UFH bridging of dabigatran, only the anti-Xa activity should be considered suitable to measure UFH effect, as activated partial thromboplastin time (APTT) and (dilute) thrombin time will be prolonged by both drugs. ${ }^{63}$ In the case of direct FXa inhibitors, alternatives to APTT or anti-Xa measurements are required, since both anticoagulant types affect these tests, leading to supra-therapeutic anti-Xa values. ${ }^{64}$ Testing options to address this could include (1) an UFH-calibrated thrombin time test or (2) neutralizing the DOAC effect in vitro using aforementioned neutralizing products. In studies using drug-enriched plasma, DOAC-Stop extracts DOACs efficiently with no effect on heparintype anticoagulants, but it binds argatroban and hirudin-type anticoagulants. ${ }^{45}$ To date, data on the efficacy of UFH monitoring in the presence of such compounds or using thrombin time calibration curve are lacking.

\section{DOAC and Thrombin Generation Assays}

Global tests such as the TGA have been described as promising to assess the pharmacodynamic profile of anticoagulants. ${ }^{65,66}$ Given the known DOAC thrombin generation profiles, the concentration thresholds proposed in the literature may provide highly different anticoagulant activities in a particular patient and TGA may be seen as another way of expressing and assessing the degree of anticoagulation in DOAC-treated patients (-Fig. 2). ${ }^{24,66-71}$ The ST Genesia (Diagnostica Stago, Asnières sur Seine Cedex, France), an automated analyzer for thrombin generation testing has the potential for a wide implementation in routine laboratories. Preliminary observations showed that thrombin generation testing is affected by all anticoagulant drugs, suggesting that this assay could be useful in assessing DOAC activity, but this deserves further confirmation in larger cohorts to validate this approach since to date, the role of TGA for clinical decision-making in DOAC-treated patients is not clear. ${ }^{68,70-72}$

\section{Limitations of Laboratory Testing}

Previously, the ICSH DOAC Working Party provided provisional guidance for the effect of DOACs on commonly ordered coagulation assays. ${ }^{1}$ The limitations for assessing DOAC presence, pharmacokinetics or pharmacodynamics using screening or global assays, or other coagulation tests are still present, although the use of neutralizing systems appears promising. DOAC-neutralizing systems have not been fully evaluated for all tests or test platforms and their use and interpretations must employ a degree of caution. ${ }^{1}$ Local verification of in vitro neutralizing agents (activated charcoal or filters) to assure (1) adequate DOAC neutralization by using sensitive techniques and (2) no deleterious effect on the test method is required prior to clinical use.

\section{Consensus Recommendations}

- Caution should be used when performing and interpreting the results from any coagulation test result from a DOACtreated patient.

- In vitro use of DOAC-neutralizing agents must be used with caution and must be locally verified prior to clinical use.

- Select thrombophilia test methods (e.g., clot-based measurement of protein $C$ or LA) can show interference at low DOAC concentrations. Use of DOAC-neutralizing products

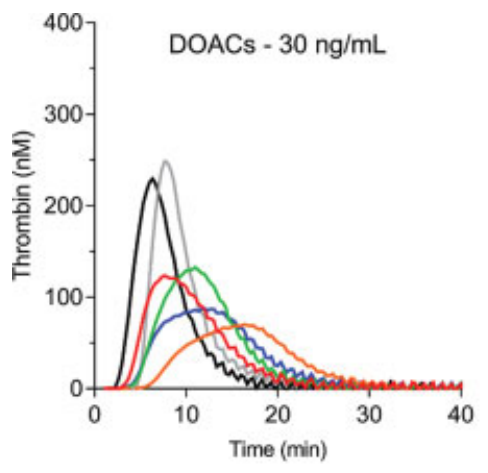

_ normal pooled plasma

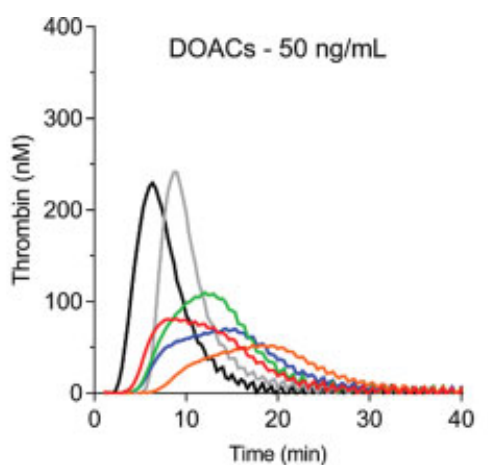

- apixaban
- betrixaban - edoxaban

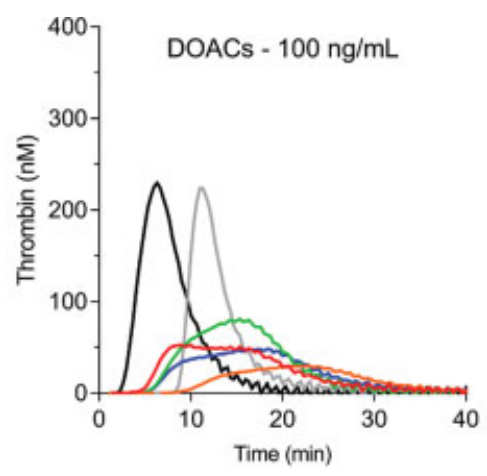

- rivaroxaban

Fig. 2 The thrombogram parameters from thrombin generation test and representative changes at relevant concentrations of direct oral anticoagulants (DOACs). Note: Thrombin generation was triggered by 5 -pM tissue factor with 4- $\mu$ M phospholipids in absence of exogenous thrombomodulin or exogenous activated protein $C$. 
may not completely achieve DOAC reversal; thus results from some assays may refrain factitiously elevated despite neutralization.

- DOAC removal systems appear to be a suitable in vitro means of neutralizing DOAC from plasma to minimize drug interference in coagulation testing, although it is unclear whether these DOAC removal systems are interchangeable with DOAC neutralization products.

- Laboratories should have a procedure for adequately assessing and differentiating anticoagulation effect when bridging therapy is required.

- Although preliminary results are encouraging, there is currently no sufficient evidence to recommend TGAs to guide clinical decisions in a DOAC-treated patient.

- Laboratories should be aware of limitations of laboratory testing for DOAC measurements and/or effect of DOACs on coagulation assays.

\section{DOAC Reversal Agents}

\section{Andexanet Alfa}

Since the initial publication of the guidance, a specific reversal agent, andexanet alfa, was approved in the United States for rivaroxaban and apixaban when reversal of anticoagulation is needed due to life-threatening or uncontrolled bleeding, and has also been approved by the Committee for Medicinal Products for Human Use in Europe for the same application. ${ }^{3,73}$ There are two dosing strategies (low and high dose), as a bolus followed by a continuous infusion. This reversal agent will reduce the levels of direct FXa inhibitors, as measured by calibrated chromogenic anti-Xa activity. ${ }^{74}$ There is a transient rise in prothrombin $\mathrm{F} 1+2$ fragments and D-dimer value after andexanet alfa is given, and an increase in thrombin generation, which may be related to the observed concomitant TFPI inhibition. ${ }^{2,3,75,76}$ Whether this observation is due to the inhibition of TFPI or whether it is clinically important is not yet known and deserves some caution.

\section{Idarucizumab}

Idarucizumab is a specific reversal agent for dabigatran and is indicated in adult dabigatran etexilate-treated patients with dabigatran etexilate when rapid reversal of its anticoagulant effects is required such as in emergency surgery or urgent procedures and in life-threatening or uncontrolled bleeding. It has been approved for the same indications in both the United States and Europe based on the results from the REVERSE-AD study, which showed the efficacy and safety of idarucizumab to reverse the anticoagulant effect of dabigatran in dabigatran-treated patients who experienced serious bleeding or required urgent invasive procedures. ${ }^{77-79}$ Although the product has been on the market for more than 3 years, only a small case series and four large studies evaluated its safety and efficacy in a real-world setting. ${ }^{80-84}$ No specific dabigatran monitoring is currently recommended before reversal or during follow-up according to the prescribing information as approved by the regulatory authorities. $^{77,78}$

\section{DOAC Reversal Agents and the Laboratory}

As andexanet alfa reduces the DOAC level after bolus and/or infusion, but DOAC levels recover following cessation of infusion, it can be speculated that post-infusion coagulation tests may be affected (for rivaroxaban, the residual drug level after andexanet alfa treatment was $\sim 40 \%$ from pre-treatment levels, a concentration that can still affect coagulation tests). ${ }^{85}$ Evaluating post-infusion rivaroxaban or apixaban anti-Xa measurements is not supported by current Food and Drug Administration (FDA) recommendations as they indicate that the likelihood of using anti-FXa activity as a surrogate endpoint to predict a clinical benefit of haemostasis is not evident. ${ }^{3}$ However, pre-treatment DOAC measurements may be warranted $^{86}$ to determine whether the low- or high-dose regimen should be used, as well as providing the potential to avoid unnecessary patient exposure to reversal antidotes. ${ }^{87}$ However, this cannot be detrimental to the patients and should not delay the administration of reversal agents, especially in DOAC-treated patients with life-threatening bleeding, such as intracranial bleeding or in those requiring emergency surgery for life-threatening conditions such as a ruptured aortic aneurysm. In such context, rapid POC device with appropriate clinical performance is highly needed to guide the best strategy for patient's management.

It should be noted that the current dosing recommendations of andexanet alfa are based on both the dose and the time since the last intake of apixaban and rivaroxaban. ${ }^{2,3}$ However, in an unconscious patient, such information cannot always be obtained. The plasma concentration of apixaban or rivaroxaban could be of interest in this context, but the definition of specific thresholds based on these plasma concentrations at the time of the admission is not yet available. Otherwise, specific tests are required in the unconscious patient to discriminate between the type of anticoagulant (IIa or Xa inhibitor) and could be useful to follow the efficacy of andexanet alfa administration. Several POC devices are currently under investigation that may prove useful in this setting (see the section on POC device below). Importantly, commercially available anti-FXa assays measure FXa inhibitors using drug-specific calibrators and controls. However, there are limitations when these assays are used for measuring DOAC concentration in andexanet alfa patient samples. One of the limitations is the large sample dilution in the assay set-up, which causes dissociation of the inhibitor from the andexanet alfa-inhibitor complex (due to the reversible binding equilibrium of the andexanet alfa inhibitor), resulting in an erroneous elevation of the anti-FXa activity following andexanet alfa administration. Therefore, some anti-Xa assays may have to be modified to be utilized if chromogenic anti-Xa assays are used to evaluate the degree of reversal of andexanet alfa. ${ }^{88}$

For dabigatran reversal, a single dose of idarucizumab (Praxbind, Boehringer Ingelheim) will bind up to $1,000 \mathrm{ng} / \mathrm{mL}$ of the drug, but there appears to be a rebound or dissociation effect after 12 to 24 hours. As such, measurements of dabigatran may predict the need for secondary dosing of this reversal agent. ${ }^{19}$ In a retrospective study, it has been shown that the 
assessment of dabigatran levels before introducing the reversal therapy could predict the haemostasis effectiveness and the potential rebound in dabigatran levels after idarucizumab injection and that specific dabigatran threshold (i.e., $264 \mathrm{ng} / \mathrm{mL}$ as reported in this study) may be of interest to predict haemostatic ineffectiveness, dabigatran rebound, and outcomes after reversal. ${ }^{80}$ Idarucizumab has no known impact on coagulation parameters by itself.

Other agents that have been used for DOAC reversal include three- or four-factor prothrombin complex concentrates (PCCs) or activated PCCs. ${ }^{89-94}$ These non-specific reversal agents are expected to have an impact on coagulation screening tests but not on anti-Xa- or anti-Ila-based assays, but data are currently limited with DOAC reversal strategies. The amount of PCC needed to stop DOAC-induced bleeding may depend on the residual DOAC concentration at the time PCC is administered. ${ }^{95}$ However, although clinical bleeding may be sufficiently controlled with a single dose of PCC, the impact of DOAC on some laboratory tests may not be completely abolished as the relationship between residual DOAC level as measured by laboratory testing and the risk of uncontrolled bleeding is currently unclear. $^{18}$

\section{Consensus Recommendations}

- For andexanet alfa, due to its pharmacodynamic profile, the use of anti-Xa techniques for the evaluation of post-infusion rivaroxaban or apixaban anti-Xa activity is not supported.

- Post-andexanet alfa treatment, testing of apixaban and rivaroxaban concentrations is affected by anti-Xa methods that use high sample pre-dilutions causing factitiously elevated FXa DOAC results.

- For idarucizumab, measurements of dabigatran may predict the need for secondary dosing of this reversal agent since the presence of idarucizumab does not seem to interfere with dabigatran.

- It is currently unclear how to best assess the reversal efficacy of specific antidotes (i.e., andexanet alfa or idarucizumab) using laboratory tests and requires further investigation.

- PCC administration should not be monitored by measurement of DOAC concentrations that will not be modified.

- Assessment of DOAC reversal by global or specialized laboratory assays is method dependent and may be misleading.

\section{DOAC Point-of-Care Testing}

The widespread use of DOACs and the need for urgent determination in aforementioned specific clinical situations have spurred several investigators and manufacturers to pursue POCT technologies for measuring (or quantifying) DOAC effect. ${ }^{96-98}$ Included are microfluidic technologies $^{98-101}$ and surface acoustic wave (SAW) technologies. ${ }^{102}$ Although the preliminary findings are promising, shortcomings include use of an animal model, ${ }^{101}$ or in vitro enriched DOAC blood, ${ }^{99}$ data from a small series of patients ${ }^{99,100}$ and only a limited number of DOACs assessed. ${ }^{99,101,102}$ In addition, these methods appear to be several years from actual clinical implementation, as none have undergone the rigors of in vitro device (IVD) clinical trials.
The TEG 6s NOAC assay is a cartridge currently undergoing clinical trials which can be used for qualitative DOAC assessment. ${ }^{103-105}$ The four-channels, single-use NOAC cartridge contains kaolin in channel 1, ecarin in channel 2, FXa in channel 3, and abciximab in channel 4, with channels 2 and 3 providing differentiation in DOAC effect of prolonged clotting times. In a small series of patients receiving dabigatran, rivaroxaban, or apixaban, the receiver operating characteristic (ROC) analysis yielded a sensitivity of 94 and $92 \%$ for channel 2 (dabigatran) and channel 3 (direct FXa inhibitors), respectively. ${ }^{105}$ Since the last publication, ${ }^{1}$ Harenberg et al published recommendations regarding the use of a urine dipstick device which was shown to be sensitive and specific to determine the presence of both FXa and factor Ila inhibitors in urine samples. The evaluation of the DOAC dipstick test in emergency medicine and other patient groups is currently ongoing. This device allows qualitative determination of direct thrombin or FXa inhibitors and may aid in generating algorithms for clinical decision-making in a bleeding patient or for a patient requiring urgent surgical intervention in conjunction with laboratory plasma-based assays. ${ }^{106,107}$ However, cautious and informed use of this urine DOAC screening method is required, as there is no direct relationship between plasma and urine DOAC concentrations despite the excellent sensitivity and specificity of the device. In any case, if DOAC is detected in the urine by the dipstick device, it should be confirmed with more specific testing to confirm the presence of DOAC in the blood.

Although not specifically a POCT, dried blood spot (DBS) technology may be a suitable alternative to traditional blood collection for non-emergent assessment of DOACs. ${ }^{98,108}$ This method would allow for at-home collection using finger stick blood collection onto filter paper, which is then sent via postal service to a laboratory that can provide a quantitative DOAC level determination using tandem mass spectrometry. However, it must be emphasized that mass spectrometry testing using DBS must also be validated using DBS-collected samples. In addition, the haematocrit level of blood may cause systematic bias in analyte measurement in DBS samples, and it is also a practical challenge to train and ensure appropriate DBS collection procedures being performed by in-home patients since inappropriate DBS collection can cause significant variability in assay measurement. However, volumetric absorptive microsampling (VAMS), a recent microsampling technique used to obtain dried specimens of blood, promises to bring some significant advantages over DBS, related to sampling volume accuracy, haematocrit (HCT) dependence, pre-treatment and automation. ${ }^{109}$ We also must emphasize that the lack of availability of liquid chromatography with tandem mass spectrometry (LC-MS)/MS in smaller laboratories, long turnaround time, cost and labour-intensive sample preparation restrict the use of this strategy in most laboratories. However, if the testing is not urgent, the VAMS collection device can be sent to a reference laboratory which can provide standardized and validated DOAC analyses overcoming the potential geographical limitations. ${ }^{110}$ 


\section{Consensus Recommendations}

- Tests and technologies of various POCT devices may provide totally different type of results.

- Global coagulation POCT like SAWs and thromboelastometry are promising for identifying the drug on board, but their usefulness to evaluate the degree of anticoagulation is still unclear and further investigations are warranted.

- Rapid urine testing may rapidly identify the DOAC type taken, which may assist clinical decision-making.

- DBS and VAMS technology may be of interest to perform pharmacokinetic investigations without suffering from geographical limitations and rapid access to specialized laboratories.

\section{External Quality Control}

Most international external quality control (EQA) programmes now have established EQA exercises for DOACs and demonstrate a wide implementation of specific DOAC testing in certain regions of the world..$^{11-118}$ Nevertheless, in regions where the regulatory authorities have refused the approval of these specific kits, access to drug measurements may be limited to specialized laboratories. In addition, only few undertake the in-house validation of these techniques refraining the clinicians to ask for these specific drug measurements. This is detrimental to the patients, especially knowing the limitations of routine coagulation tests for DOAC testing which are used instead. These routine tests showed a poor analytical and clinical performance in the different clinical settings where DOAC measurement may be beneficial. 6,119

Some international EQA programmes have also undertaken and published studies looking at DOAC interference in haemostasis tests. ${ }^{111-118}$ Some have also undertaken studies looking at neutralizing the interference of DOACs in haemostasis tests. ${ }^{120}$ Although differences were seen between the various methodologies, reliable and reproducible DOAC levels were measured overall. A 5-year overview of experience for the quality performance of DOACs over a large concentration range showed a good correlation between the different methodologies. Although no international calibration standards were available, the overall coefficients of variation (CVs) were small for dabigatran, rivaroxaban and apixaban, and were also comparable to the CVs (range: 3-14\%) for the international normalized ratio derived from the same years. ${ }^{113}$

The outcome for the various methodologies in the EQA surveys could be used to establish clinical decision rules adapted for specific reagents. This is especially relevant in the ranges approaching clinical decision limits. Laboratories are strongly encouraged to participate in EQA programmes that adequately address the pharmacodynamics and pharmacokinetics of DOACs, as well as the identification of DOAC sources of interference in other coagulation assays.

\section{Consensus Recommendations}

- Laboratories are strongly encouraged to participate in EQA programmes that assess DOAC effects on screening tests and quantitative measurements, as well as their interference in other coagulation assays.

- Collecting information on DOAC testing availability and performance around the world is necessary to help various working parties to provide guidelines.

\section{Future Perspectives}

emergence of DOACs and their increased use as well as the introduction of anticoagulants in future will provide a challenge for clinical laboratories. It is likely that DOAC use will increase as clinical trials are currently in the process for paediatric use. Dabigatran use in paediatric patients with VTE demonstrated non-inferiority to standard treatment. ${ }^{121}$ Rivaroxaban use in paediatric patients (Einstein-Jr clinical trial, NCT02234843) is completed and awaiting approval for use in cerebral venous thrombosis ${ }^{122}$ and catheter-related VTE. ${ }^{123}$ Summary of the use of rivaroxaban in the paediatric population is also available elsewhere. ${ }^{124}$ Apixaban is being evaluated in VTE reduction in paediatric patients with congenital heart disease ${ }^{125}$ and acute lymphoblastic. ${ }^{126}$ Edoxaban is currently under investigation for use in paediatric patients at risk of thromboembolic complications due to heart disease (www.clinicaltrials.gov; NCT 03395639). Other DOAC clinical trials include use for VTE prevention in patients with cancer (clinicaltrials.gov; NCT03240120; NCT03692065), post-bariatric surgery (clinicaltrials.gov; NCT03522259; NCT02406885), SARS-CoV-2 infections (clinicaltrials.gov; NCT04757857; NCT04650087; NCT04542408) and others will likely increase the use of DOACs once efficacy has been established.

In addition to the increase in use of DOACs in multiple settings with unclear expected "on-therapy" ranges and drug detection requirements, other technical considerations and concerns for the clinical laboratory would be the other anticoagulants under investigation. ${ }^{127}$ As these drugs effect in vivo anticoagulation, it is likely their ex vivo effect will also add another layer of complexity and concern for the clinical coagulation laboratory. The hope and promise of POC methods with increased sensitivity and specificity for novel anticoagulants, including DOACs, may alleviate some burden on the laboratory.

\section{What is known about this topic?}

- Direct oral anticoagulants are used worldwide for several thromboembolic indications.

- The 2018 ICSH document provided haemostasis-related guidance for clinical laboratories.

- This study addressed all phases of laboratory DOAC measurements.

\section{What does this paper add?}

- This guidance updates the 2018 edition with a particular focus on antidotes, POCT and global coagulation tests. 
Funding

None.

\section{Conflict of Interest}

Among the authors, J.D. is the CEO and founder of QUALIblood s.a., a contract research organization manufacturing the DP-Filter, is a co-inventor of the DPFilter (patent application number: PCT/ET2019/052903) and reports personal fees from Daiichi Sankyo, Mithra Pharmaceuticals, Stago, Roche and Roche Diagnostics outside the submitted work. E.L.-L received lecture fees and consulting fees from Bayer, Boehringer Ingelheim, Bristol-Myers Squibb-Pfizer, Daiichi Sankyo, Portola, CSL Behring, Leo and Aspen. She received external funds for conducting a clinical contract study from Bayer and Daiichi Sankyo, for a research project that she initiated from Bayer AG, Bristol-Myers Squibb-Pfizer, Daiichi Sankyo and CSL Behring. E.J.F. and S.M.B. have no conflict of interest. I.G.T. received consulting fees from Bayer, Boehringer Ingelheim and Bristol-Myers Squibb-Pfizer. R.C.G. reports personal fees from Diagnostica Grifols, Siemens Healthcare Diagnostics and Diagnostica Stago, and has provided expert testimony on dabigatran and rivaroxaban testing.

\section{References}

1 Gosselin RC, Adcock DM, Bates SM, et al. International Council for Standardization in Haematology (ICSH) recommendations for laboratory measurement of direct oral anticoagulants. Thromb Haemost 2018;118(03):437-450

2 European Medicines Agency. Ondexxya: Summary of Product Characteristics. 2021. Accessed March 3, 2021 at: https://www. ema.europa.eu/en/medicines/human/EPAR/ondexxya

3 Food and Drug Administration. Andexxa: Prescribing Information. 2018. Accessed March 3, 2021 at: https://www.fda.gov/vaccines-blood-biologics/cellular-gene-therapy-products/andexxa-coagulation-factor-xa-recombinant-inactivatedzhzo

4 Witt DM, Nieuwlaat R, Clark NP, et al. American Society of Hematology 2018 guidelines for management of venous thromboembolism: optimal management of anticoagulation therapy. Blood Adv 2018;2(22):3257-3291

5 Steffel J, Verhamme P, Potpara TS, et al; ESC Scientific Document Group. The 2018 European Heart Rhythm Association Practical Guide on the use of non-vitamin K antagonist oral anticoagulants in patients with atrial fibrillation. Eur Heart J 2018;39(16): 1330-1393

6 Douxfils J, Ageno W, Samama CM, et al. Laboratory testing in patients treated with direct oral anticoagulants: a practical guide for clinicians. J Thromb Haemost 2018;16(02):209-219

7 Ruff CT, Giugliano RP, Braunwald E, et al. Association between edoxaban dose, concentration, anti-Factor Xa activity, and outcomes: an analysis of data from the randomised, double-blind ENGAGE AF-TIMI 48 trial. Lancet 2015;385(9984):2288-2295

8 Reilly PA, Lehr T, Haertter S, et al; RE-LY Investigators. The effect of dabigatran plasma concentrations and patient characteristics on the frequency of ischemic stroke and major bleeding in atrial fibrillation patients: the RE-LY Trial (Randomized Evaluation of Long-Term Anticoagulation Therapy). J Am Coll Cardiol 2014;63 (04):321-328

9 Zhang L, Yan X, Fox KAA, et al. Associations between modelpredicted rivaroxaban exposure and patient characteristics and efficacy and safety outcomes in patients with non-valvular atrial fibrillation. J Thromb Thrombolysis 2020;50(01):20-29

10 Reinecke I, Solms A, Willmann S, et al. Associations between model-predicted rivaroxaban exposure and patient characteristics and efficacy and safety outcomes in the prevention of venous thromboembolism. J Thromb Thrombolysis 2020;50 (01):12-19

11 Solms A, Willmann S, Reinecke I, et al. Associations between model-predicted rivaroxaban exposure and patient characteristics and efficacy and safety outcomes in the treatment of venous thromboembolism. J Thromb Thrombolysis 2020;50 (01):1-11

12 Toorop MMA, Lijfering WM, Scheres LJJ. The relationship between DOAC levels and clinical outcomes: the measures tell the tale. J Thromb Haemost 2020;18(12):3163-3168

13 Douxfils J, Mullier F, Dogné JM. Dose tailoring of dabigatran etexilate: obvious or excessive? Expert Opin Drug Saf 2015;14 (08):1283-1289

14 Kato ET, Giugliano RP, Ruff CT, et al. Efficacy and safety of edoxaban in elderly patients with atrial fibrillation in the ENGAGE AF-TIMI 48 trial. J Am Heart Assoc 2016;5(05):e003432

15 Buckley LF, Rybak E, Aldemerdash A, Cheng JW, Fanikos J. Direct oral anticoagulants in patients with atrial fibrillation and renal impairment, extremes in weight, or advanced age. Clin Cardiol 2017;40(01):46-52

16 Chan KE, Giugliano RP, Patel MR, et al. Nonvitamin K anticoagulant agents in patients with advanced chronic kidney disease or on dialysis with AF. J Am Coll Cardiol 2016;67(24):2888-2899

17 Levy JH, Ageno W, Chan NC, Crowther M, Verhamme P, Weitz JISubcommittee on Control of Anticoagulation. When and how to use antidotes for the reversal of direct oral anticoagulants: guidance from the SSC of the ISTH. J Thromb Haemost 2016;14 (03):623-627

18 Lindhoff-Last E. Direct oral anticoagulants (DOAC): management of emergency situations. Hamostaseologie 2017;37(04): 257-266

19 Gendron N, Gay J, Lemoine M, Gaussem P, Lillo-Le-Louet A, Smadja DM. Usefulness of initial plasma dabigatran concentration to predict rebound after reversal. Haematologica 2018;103 (05):e226-e229

20 Tripodi A. To measure or not to measure direct oral anticoagulants before surgery or invasive procedures: reply. J Thromb Haemost 2016;14(12):2559-2561

21 Tripodi A. To measure or not to measure direct oral anticoagulants before surgery or invasive procedures. J Thromb Haemost 2016;14(07):1325-1327

22 Tripodi A, Marongiu F, Moia M, et al. The vexed question of whether or not to measure levels of direct oral anticoagulants before surgery or invasive procedures. Intern Emerg Med 2018; 13(07):1029-1036

23 Albaladejo P, Bonhomme F, Blais N, et al; French Working Group on Perioperative Hemostasis (GIHP) Management of direct oral anticoagulants in patients undergoing elective surgeries and invasive procedures: updated guidelines from the French Working Group on Perioperative Hemostasis (GIHP) - September 2015. Anaesth Crit Care Pain Med 2017;36(01):73-76

24 Rimsans J, Douxfils J, Smythe MA, et al. Overview and practical application of coagulation assays in managing anticoagulation with direct oral anticoagulants (DOACs). Curr Pharmacol Rep 2020;6:241-259

25 Shaw JR, Li N, Vanassche T, et al. Predictors of preprocedural direct oral anticoagulant levels in patients having an elective surgery or procedure. Blood Adv 2020;4(15):3520-3527

26 Douketis JD, Spyropoulos AC, Duncan J, et al. Perioperative management of patients with atrial fibrillation receiving a direct oral anticoagulant. JAMA Intern Med 2019;179(11): 1469-1478 
27 Martin K, Beyer-Westendorf J, Davidson BL, Huisman MV, Sandset PM, Moll S. Use of the direct oral anticoagulants in obese patients: guidance from the SSC of the ISTH. J Thromb Haemost 2016;14(06):1308-1313

28 Moll S, Crona DJ, Martin K. Direct oral anticoagulants in extremely obese patients: OK to use? Res Pract Thromb Haemost 2018;3(02):152-155

29 Testa S, Legnani C, Antonucci E, et al; Coordinator of START2Register. Drug levels and bleeding complications in atrial fibrillation patients treated with direct oral anticoagulants. J Thromb Haemost 2019;17(07):1064-1072

30 Testa S, Paoletti O, Legnani C, et al. Low drug levels and thrombotic complications in high-risk atrial fibrillation patients treated with direct oral anticoagulants. J Thromb Haemost 2018; 16(05):842-848

31 Salmonson T, Dogné JM, Janssen H, Garcia Burgos J, Blake P. Nonvitamin-Koral anticoagulants and laboratory testing: now and in the future: views from a workshop at the European Medicines Agency (EMA). Eur Heart J Cardiovasc Pharmacother 2017;3(01): $42-47$

32 Willmann S, Thelen K, Kubitza D, et al. Pharmacokinetics of rivaroxaban in children using physiologically based and population pharmacokinetic modelling: an EINSTEIN-Jr phase I study. Thromb J 2018;16:32

33 Rahman M, George C, Monagle P. Hot topics in coagulation testing: important considerations for testing children for bleeding/thrombotic disorders. Int J Lab Hematol 2020;42 (Suppl 1):68-74

34 Gosselin R, Douxfils J. Measuring direct oral anticoagulants. In: Favaloro EJ, Lippi G, eds. Hemostasis and Thrombosis. New York, NY: Humana Press; 2017:217-225

35 Gosselin RC, Douxfils J. Ecarin based coagulation testing. Am J Hematol 2020;95(07):863-869

36 Gosselin RC, Gosselin R, Douxfils J, Adcock D. Clinical pearls: laboratory assessments of direct oral anticoagulants (DOACS). Hamostaseologie 2017;37(04):295-301

37 Siriez R, Dogné JM, Gosselin R, Laloy J, Mullier F, Douxfils J. Comprehensive review of the impact of direct oral anticoagulants on thrombophilia diagnostic tests: practical recommendations for the laboratory. Int J Lab Hematol 2021;43(01):7-20

38 Godier A, Martin AC, Lessire S, Mullier F, Leblanc I, GouinThibault I. Concentrations of direct oral anticoagulants according to guidelines for the periprocedural management of low bleeding risk procedures. Anaesth Crit Care Pain Med 2020;39(01): $121-122$

39 Sevenet PO, Cucini V, Hervé T, et al. Evaluation of DOAC Filter, a new device to remove direct oral anticoagulants from plasma samples. Int J Lab Hematol 2020;42(05):636-642

40 Kopytek M, Ząbczyk M, Malinowski KP, Undas A, Natorska J. DOAC-Remove abolishes the effect of direct oral anticoagulants on activated protein $C$ resistance testing in real-life venous thromboembolism patients. Clin Chem Lab Med 2020;58(03): 430-437

41 Exner T, Rigano J, Favaloro EJ. The effect of DOACs on laboratory tests and their removal by activated carbon to limit interference in functional assays. Int J Lab Hematol 2020;42(Suppl 1):41-48

42 Platton S, Hunt C. Influence of DOAC Stop on coagulation assays in samples from patients on rivaroxaban or apixaban. Int J Lab Hematol 2019;41(02):227-233

43 Jourdi G, Delrue M, Stepanian A, et al. Potential usefulness of activated charcoal (DOAC remove ${ }^{\circledR}$ ) for dRVVT testing in patients receiving direct oral anticoagulants. Thromb Res 2019;184:86-91

44 Exner T, Favresse J, Lessire S, Douxfils J, Mullier F. Clotting test results correlate better with DOAC concentrations when expressed as a "correction ratio"; results before/after extraction with the DOAC Stop reagent. Thromb Res 2019;179:69-72
45 Exner T, Ahuja M, Ellwood L. Effect of an activated charcoal product (DOAC Stop ${ }^{\mathrm{TM}}$ ) intended for extracting DOACs on various other APTT-prolonging anticoagulants. Clin Chem Lab Med 2019;57(05):690-696

46 Cox-Morton S, MacDonald S, Thomas W. A diagnostic solution for haemostasis laboratories for patients taking direct oral anticoagulants using DOAC-Remove. Br J Haematol 2019;187(03): 377-385

47 Exner T, Michalopoulos N, Pearce J, Xavier R, Ahuja M. Simple method for removing DOACs from plasma samples. Thromb Res 2018;163:117-122

48 De Kesel PM, Devreese KMJ. Direct oral anticoagulant adsorption: impact on lupus anticoagulant testing: review of the literature and evaluation on spiked and patient samples. J Thromb Haemost 2020;18(08):2003-2017

49 Ząbczyk M, Kopytek M, Natorska J, Undas A. The effect of DOACStop on lupus anticoagulant testing in plasma samples of venous thromboembolism patients receiving direct oral anticoagulants. Clin Chem Lab Med 2019;57(09):1374-1381

50 Monteyne T, De Kesel P, Devreese KMJ. Interference of DOAC Stop and DOAC Remove in the thrombin generation assay and coagulation assays. Thromb Res 2020;192:96-99

51 Kopatz WF, Brinkman HJM, Meijers JCM. Use of DOAC Stop for elimination of anticoagulants in the thrombin generation assay. Thromb Res 2018;170:97-101

52 Bouvy C, Evrard J, Siriez R, et al. P220: Removal of DOACs from plasma: performance comparison and pre-analytical considerations of three different devices. ECTH 2018 Abstract Book 2018

53 Depreter B, Devreese KM. Dilute Russell's viper venom time reagents in lupus anticoagulant testing: a well-considered choice. Clin Chem Lab Med 2017;55(01):91-101

54 Hillarp A, Strandberg K, Gustafsson KM, Lindahl TL. Unveiling the complex effects of direct oral anticoagulants on dilute Russell's viper venom time assays. J Thromb Haemost 2020;18(08): 1866-1873

55 Sokol J, Nehaj F, Ivankova J, Mokan M, Mokan M. First evidence: rivaroxaban and apixaban reduce thrombin-dependent platelet aggregation. J Thromb Thrombolysis 2018;46(03):393-398

56 Perzborn E, Heitmeier S, Laux V. Effects of rivaroxaban on platelet activation and platelet-coagulation pathway interaction: in vitro and in vivo studies. J Cardiovasc Pharmacol Ther 2015;20(06):554-562

57 Shimizu M, Natori T, Tsuda K, et al. Thrombin-induced platelet aggregation: effect of dabigatran using automated platelet aggregometry. Platelets 2020;31(03):360-364

58 Jourdi G, Bachelot-Loza C, Mazoyer E, et al. Effect of rivaroxaban and dabigatran on platelet functions: in vitro study. Thromb Res 2019;183:159-162

59 Königsbrügge O, Weigel G, Quehenberger P, Pabinger I, Ay C. Plasma clot formation and clot lysis to compare effects of different anticoagulation treatments on hemostasis in patients with atrial fibrillation. Clin Exp Med 2018;18(03):325-336

60 Carter RLR, Talbot K, Hur WS, et al. Rivaroxaban and apixaban induce clotting factor Xa fibrinolytic activity. J Thromb Haemost 2018;16(11):2276-2288

61 Ammollo CT, Semeraro F, Incampo F, Semeraro N, Colucci M. Dabigatran enhances clot susceptibility to fibrinolysis by mechanisms dependent on and independent of thrombin-activatable fibrinolysis inhibitor. J Thromb Haemost 2010;8(04):790-798

62 Semeraro F, Incampo F, Ammollo CT, et al. Dabigatran but not rivaroxaban or apixaban treatment decreases fibrinolytic resistance in patients with atrial fibrillation. Thromb Res 2016; 138:22-29

63 Douxfils J, Tamigniau A, Chatelain B, Goffinet C, Dogné JM, Mullier F. Measurement of non-VKA oral anticoagulants versus classic ones: the appropriate use of hemostasis assays. Thromb J 2014;12:24 
64 Macedo KA, Tatarian P, Eugenio KR. Influence of direct oral anticoagulants on anti-factor Xa measurements utilized for monitoring heparin. Ann Pharmacother 2018;52(02):154-159

65 Sairaku A, Nakano Y, Onohara Y, et al. Residual anticoagulation activity in atrial fibrillation patients with temporary interrupted direct oral anticoagulants: comparisons across 4 drugs. Thromb Res 2019;183:119-123

66 Evrard J, Hardy M, Dogné JM, et al. Are the DOAC plasma level thresholds appropriate for clinical decision-making? A reappraisal using thrombin generation testing. Int J Lab Hematol 2021;43(01):e48-e51

67 Reda S, Morimont L, Douxfils J, Rühl H. Can we measure the individual prothrombotic or prohemorrhagic tendency by global coagulation tests? Hamostaseologie 2020;40(03):364-378

68 Douxfils J, Morimont L, Bouvy C, et al. Assessment of the analytical performances and sample stability on ST Genesia system using the STG-DrugScreen application. J Thromb Haemost 2019;17(08):1273-1287

69 Siguret V, Abdoul J, Delavenne X, et al. Rivaroxaban pharmacodynamics in healthy volunteers evaluated with thrombin generation and the active protein $C$ system: modeling and assessing interindividual variability. J Thromb Haemost 2019;17(10): 1670-1682

70 Metze M, Pfrepper C, Klöter T, et al. Inhibition of thrombin generation 12 hours after intake of direct oral anticoagulants. Res Pract Thromb Haemost 2020;4(04):610-618

71 Pfrepper C, Metze M, Siegemund A, Klöter T, Siegemund T, Petros S. Direct oral anticoagulant plasma levels and thrombin generation on ST Genesia system. Res Pract Thromb Haemost 2020;4 (04):619-627

72 Hemker HC, Al Dieri R, Béguin S. Heparins: a shift of paradigm. Front Med (Lausanne) 2019;6:254

73 Favresse J, Hardy M, van Dievoet MA, et al. Andexanet alfa for the reversal of factor Xa inhibitors. Expert Opin Biol Ther 2019;19 (05):387-397

74 Lu G, DeGuzman FR, Hollenbach SJ, et al. A specific antidote for reversal of anticoagulation by direct and indirect inhibitors of coagulation factor Xa. Nat Med 2013;19(04):446-451

75 Siegal DM, Curnutte JT, Connolly SJ, et al. Andexanet alfa for the reversal of factor Xa Inhibitor activity. N Engl J Med 2015;373 (25):2413-2424

76 Connolly SJ, Crowther M, Eikelboom JW, et al; ANNEXA-4 Investigators. Full Study report of andexanet alfa for bleeding associated with factor Xa inhibitors. N Engl J Med 2019;380(14): 1326-1335

77 European Medicines Agency. Praxbind: Summary of Product Characeteristics. 2021. Accessed February 22, 2021 at: https:/ www.ema.europa.eu/documents/product-information/praxbindepar-product-information_en.pdf

78 Food and Drug Administration. Praxbind: Prescribing Information. Accessed February 23, 2021 at: https://www.accessdata.fda.gov/ drugsatfda_docs/label/2018/761025s002lbl.pdf

79 Pollack CV Jr, Reilly PA, van Ryn J, et al. Idarucizumab for dabigatran reversal: full cohort analysis. N Engl J Med 2017; 377(05):431-441

80 Gendron N, Chocron R, Billoir P, et al. Dabigatran level before reversal can predict hemostatic effectiveness of idarucizumab in a real-world setting. Front Med (Lausanne) 2020;7:599626

81 Gendron N, Feral-Pierssens AL, Jurcisin I, et al. Real-world use of idarucizumab for dabigatran reversal in three cases of serious bleeding. Clin Case Rep 2017;5(03):346-350

82 Singh S, Nautiyal A, Belk KW. Real world outcomes associated with idarucizumab: population-based retrospective cohort study. Am J Cardiovasc Drugs 2020;20(02):161-168

83 van der Wall SJ, van Rein N, van den Bemt B, et al. Performance of idarucizumab as antidote of dabigatran in daily clinical practice. Europace 2019;21(03):414-420
84 Kermer P, Eschenfelder CC, Diener HC, et al. Antagonizing dabigatran by idarucizumab in cases of ischemic stroke or intracranial hemorrhage in Germany-Updated series of 120 cases. Int J Stroke 2020;15(06):609-618

85 Connolly SJ, Milling TJ Jr, Eikelboom JW, et al; ANNEXA-4 Investigators. Andexanet alfa for acute major bleeding associated with factor Xa inhibitors. N Engl J Med 2016;375(12):1131-1141

86 Hunt BJ, Neal MD, Stensballe J. Reversing anti-factor Xa agents and the unmet needs in trauma patients. Blood 2018;132(23): 2441-2445

87 Connors JM. Testing and monitoring direct oral anticoagulants. Blood 2018;132(19):2009-2015

88 European Medicines Agency. Direct Health Care Professional Communication (DHCP): Ondexxya (Andexanet Alfa): Commercial Anti-FXa Activity Assays Are Unsuitable for Measuring AntiFXa Activity Following Administration of Andexanet Alfa. Accessed October 18, 2020 at: https://www.ema.europa.eu/en/ human-regulatory/post-authorisation/pharmacovigilance/direct-healthcare-professional-communications

89 Barra ME, Das AS, Hayes BD, et al. Evaluation of andexanet alfa and four-factor prothrombin complex concentrate (4F-PCC) for reversal of rivaroxaban- and apixaban-associated intracranial hemorrhages. J Thromb Haemost 2020;18(07):1637-1647

90 Barzilai M, Kirgner I, Steimatzky A, et al. Prothrombin complex concentrate before urgent surgery in patients treated with rivaroxaban and apixaban. Acta Haematol 2020;143(03):266-271

91 Bavalia R, Abdoellakhan R, Brinkman HJM, et al. Emergencies on direct oral anticoagulants: management, outcomes, and laboratory effects of prothrombin complex concentrate. Res Pract Thromb Haemost 2020;4(04):569-581

92 Giffard-Quillon L, Desmurs-Clavel H, Grange C, Jourdy Y, Dargaud Y. Reversal of rivaroxaban anticoagulant effect by prothrombin complex concentrates: which dose is sufficient to restore normal thrombin generation? Thromb J 2020;18:15

93 Shaw JR, Carrier M, Dowlatshahi D, et al. Activated prothrombin complex concentrates for direct oral anticoagulant-associated bleeding or urgent surgery: hemostatic and thrombotic outcomes. Thromb Res 2020;195:21-28

94 Lindhoff-Last E, Herrmann E, Lindau S, et al. Severe hemorrhage associated with oral anticoagulants. Dtsch Arztebl Int 2020;117 (18):312-319

95 Hindricks G, Potpara T, Dagres N, et al; ESC Scientific Document Group. 2020 ESC Guidelines for the diagnosis and management of atrial fibrillation developed in collaboration with the European Association for Cardio-Thoracic Surgery (EACTS). Eur Heart J 2021;42(05):373-498

96 Patel JP, Byrne RA, Patel RK, Arya R. Progress in the monitoring of direct oral anticoagulant therapy. Br J Haematol 2019;184(06): 912-924

97 Favaloro EJ, Lippi G. Recent advances in mainstream hemostasis diagnostics and coagulation testing. Semin Thromb Hemost 2019;45(03):228-246

98 Jigar Panchal H, Kent NJ, Knox AJS, Harris LF. Microfluidics in haemostasis: a review. Molecules 2020;25(04):E833

99 Alouidor B, Sweeney RE, Tat T, Wong RK, Yoon JY. Microfluidic point-of-care ecarin-based clotting and chromogenic assays for monitoring direct thrombin inhibitors. J Extra Corpor Technol 2019;51(01):29-37

100 Frydman GH, Ellett F, Van Cott EM, et al. A new test for the detection of direct oral anticoagulants (rivaroxaban and apixaban) in the emergency room setting. Crit Care Explor 2019;1(08):e0024

101 Ansell J, Zappe S, Jiang X, et al. A novel whole blood point-of-care coagulometer to measure the effect of direct oral anticoagulants and heparins. Semin Thromb Hemost 2019;45(03):259-263

102 Harder S, Santos SMD, Krozer V, Moll J. Surface acoustic wavebased microfluidic coagulation device for monitoring anticoagulant therapy. Semin Thromb Hemost 2019;45(03):253-258 
103 Artang R, Anderson M, Nielsen JD. Fully automated thromboelastograph TEG 6s to measure anticoagulant effects of direct oral anticoagulants in healthy male volunteers. Res Pract Thromb Haemost 2019;3(03):391-396

104 Dias JD, Lopez-Espina CG, Ippolito J, et al. Rapid point-of-care detection and classification of direct-acting oral anticoagulants with the TEG 6s: implications for trauma and acute care surgery. J Trauma Acute Care Surg 2019;87(02):364-370

105 Bliden KP, Chaudhary R, Mohammed N, et al. Determination of non-Vitamin $\mathrm{K}$ oral anticoagulant (NOAC) effects using a newgeneration thrombelastography TEG 6s system. J Thromb Thrombolysis 2017;43(04):437-445

106 Harenberg J, Beyer-Westendorf J, Crowther M, et al; Working Group Members. Accuracy of a rapid diagnostic test for the presence of direct oral factor Xa or thrombin inhibitors in urine: a multicenter trial. Thromb Haemost 2020;120(01):132-140

107 Harenberg J, Schreiner R, Hetjens S, Weiss C. Detecting anti-IIa and anti-Xa direct oral anticoagulant (DOAC) agents in urine using a DOAC dipstick. Semin Thromb Hemost 2019;45(03): 275-284

108 Foerster KI, Huppertz A, Meid AD, et al. Dried-blood-spot technique to monitor direct oral anticoagulants: clinical validation of a UPLC-MS/MS-based assay. Anal Chem 2018;90(15): 9395-9402

109 Protti M, Mandrioli R, Mercolini L. Tutorial: volumetric absorptive microsampling (VAMS). Anal Chim Acta 2019;1046:32-47

110 Douxfils J, Pochet L, Lessire S, et al. Mass spectrometry in the therapeutic drug monitoring of direct oral anticoagulants. Useful or useless? Trends Analyt Chem 2016;84:41-50

111 Bonar R, Favaloro EJ, Mohammed S, et al. The effect of the direct factor Xa inhibitors apixaban and rivaroxaban on haemostasis tests: a comprehensive assessment using in vitro and ex vivo samples. Pathology 2016;48(01):60-71

112 Bonar R, Favaloro EJ, Mohammed S, Pasalic L, Sioufi J, Marsden K. The effect of dabigatran on haemostasis tests: a comprehensive assessment using in vitro and ex vivo samples. Pathology 2015; 47(04):355-364

113 Hollestelle MJ, Meijer P. International external quality assessment for measurements of direct oral anticoagulants: results and recommendations. Br J Haematol 2020;188(03):460-464

114 Jennings I, Kitchen D, Kitchen S, Woods T, Walker I. The importance of commutability in material used for quality control purposes. Int J Lab Hematol 2019;41(01):39-45

115 Van Blerk M, Bailleul E, Chatelain B, et al. Influence of apixaban on commonly used coagulation assays: results from the Belgian National External Quality Assessment Scheme. Int J Lab Hematol 2017;39(04):402-408

116 Van Blerk M, Bailleul E, Chatelain B, et al. Influence of dabigatran and rivaroxaban on routine coagulation assays. A nationwide Belgian survey. Thromb Haemost 2015;113(01):154-164

117 Van Cott EM, Smock KJ, Chen D, Hsu P, Zantek ND, Meijer P. Testing for dabigatran and rivaroxaban by clinical laboratories. Am J Hematol 2016;91(11):E464-E467

118 Smock KJ, Moser KA. What have we learned from coagulation laboratory participation in external quality programs? Int J Lab Hematol 2019;41(Suppl 1):49-55

119 Testa S, Legnani C, Tripodi A, et al. Poor comparability of coagulation screening test with specific measurement in patients receiving direct oral anticoagulants: results from a multicenter/multiplatform study. J Thromb Haemost 2016;14 (11):2194-2201

120 Favaloro EJ, Gilmore G, Arunachalam S, Mohammed S, Baker R. Neutralising rivaroxaban induced interference in laboratory testing for lupus anticoagulant (LA): a comparative study using DOAC Stop and andexanet alfa. Thromb Res 2019;180:10-19

121 Halton J, Brandão LR, Luciani M, et al; DIVERSITY Trial Investigators. Dabigatran etexilate for the treatment of acute venous thromboembolism in children (DIVERSITY): a randomised, controlled, open-label, phase $2 \mathrm{~b} / 3$, non-inferiority trial. Lancet Haematol 2021;8(01):e22-e33

122 Connor P, Sánchez van Kammen M, Lensing AWA, et al. Safety and efficacy of rivaroxaban in pediatric cerebral venous thrombosis (EINSTEIN-Jr CVT). Blood Adv 2020;4(24):6250-6258

123 Thom K, Lensing AWA, Nurmeev I, et al. Safety and efficacy of anticoagulant therapy in pediatric catheter-related venous thrombosis (EINSTEIN-Jr CVC-VTE). Blood Adv 2020;4(19): 4632-4639

124 Janssen MD. Use of XARELTO in Pediatric Patients. 2020. Accessed March 3, 2021 Mar at: https://www.janssenmd.com/xarelto/special-populations/pediatrics/use-of-xarelto-inpediatric-patients

125 Payne RM, Burns KM, Glatz AC, et al; Pediatric Heart Network Investigators. A multi-national trial of a direct oral anticoagulant in children with cardiac disease: design and rationale of the Safety of ApiXaban On Pediatric Heart disease On the preventioN of Embolism (SAXOPHONE) study. Am Heart J 2019;217:52-63

126 O'Brien SH, Li D, Mitchell LG, et al. PREVAPIX-ALL: apixaban compared to standard of care for prevention of venous thrombosis in paediatric acute lymphoblastic leukaemia (ALL): rationale and design. Thromb Haemost 2019;119(05):844-853

127 Lippi G, Gosselin R, Favaloro EJ. Current and emerging direct oral anticoagulants: state-of-the-art. Semin Thromb Hemost 2019; 45(05):490-501

128 European Medicines Agency. Eliquis - Summary of Product Characteristics. 2021. Accessed February 21, 2021 at: https:// www.ema.europa.eu/documents/product-information/eliquisepar-product-information_en.pdf

129 European Medicines Agency. Pradaxa: Summary of Product Characteristics. 2021. Accessed February 21, 2021 at: https:// www.ema.europa.eu/documents/product-information/pradaxa-epar-product-information_en.pdf

130 European Medicines Agency. Xarelto: Summary of Product Characteristics. 2021. Accessed February 21, 2021 at: https:// www.ema.europa.eu/documents/product-information/xareltoepar-product-information_en.pdf

131 Mueck W, Stampfuss J, Kubitza D, Becka M. Clinical pharmacokinetic and pharmacodynamic profile of rivaroxaban. Clin Pharmacokinet 2014;53(01):1-16

132 Weitz JI, Connolly SJ, Patel I, et al. Randomised, parallel-group, multicentre, multinational phase 2 study comparing edoxaban, an oral factor Xa inhibitor, with warfarin for stroke prevention in patients with atrial fibrillation. Thromb Haemost 2010;104(03): 633-641

133 Verhamme P, Wells PS, Segers A, et al. Dose reduction of edoxaban preserves efficacy and safety for the treatment of venous thromboembolism. An analysis of the randomised, double-blind HOKUSAI VTE trial. Thromb Haemost 2016;116(04): 747-753 